34. Cross CE, Reznick AZ, Packer L, Davis PA, Suzuki YJ, Halliwell B 1992 Oxidative damage to human plasma proteins by ozone. Free Rad Res Commun 15:347-352

35. Halliwell B, Gutteridge JMC 1990 The antioxidants of human extracellular fluids. Arch Biochem Biophys 280:1-8

36. Warner JO 1992 Immunology of cystic fibrosis. Br Med Bull 47:893-911

37. Bruce MC, Poncz L, Klinger JD, Stern RC, Tomashefski JF, Dearborn DG 1985 Biochemical and pathologic evidence for proteolytic destruction of lung connective tissue in cystic fibrosis. Am Rev Respir Dis 132:529-535

38. Britigan BE, Roeder TL, Rasmussen GT, Shasby DM, McCormick ML, Cox CD 1992 Interaction of the Pseudomonas aenuginosa secretory products pyocyanin and pyochelin generates hydroxyl radical and causes synergistic damage to endothelial cells. J Clin Invest 90:2187-2196
39. Meyer KC, Zimmerman J 1993 Neutrophil mediators, Pseudomonas, and pulmonary dysfunction in cystic fibrosis. J Lab Clin Med 121:654-661

40. Goodwin JS, Garry PJ 1983 Relationship between megadose vitamin supplementation and immunological function in a healthy elderly population. Clin Exp Immunol 51:647-653

41. Anderson R, Dosthuizen R, Maritz R, Theron A, Van Rensburg AJ 1980 The effect of increasing weekly doses of ascorbate on certain cellular and humoral immune functions in normal volunteers. Am J Clin Nutr 33:71-80

42. Boxer LA 1990 The role of antioxidants in modulating neutrophil functional responses. Adv Exp Med Biol 262:19-33

43. Terry JM, Piña SE, Mattingly SJ 1992 Role of energy metabolism in conversion of nonmucoid Pseudomonas aeruginosa to the mucoid type. Infect Immun 60:1329-1335

\title{
Announcement
}

\section{The Society for Adolescent Medicine Annual Meeting}

The Society for Adolescent Medicine, a multidisciplinary organization, will hold its annual meeting in Vancouver, British Columbia, on March 22-25, 1995, at the Vancouver Trade and Convention Center with the Waterfront Hotel as host hotel. The theme for the meeting will be "International Perspectives on Adolescent Health." In addition to addressing this topic, the meeting will present new material on a broad range of issues important to adolescent physical and emotional health, including AIDS and HIV medical management, teenage sexuality, eating disorders, depression, and risk-taking behaviors, which encompass drug and alcohol use and abuse. Meeting presentations include 3-hour clinically oriented workshops, luncheon seminars, and scientific research paper presentations and poster sessions, as well as the prestigious Gallagher Lecture Series. CME/CEUs are available.

For further information, contact the Society for Adolescent Medicine, Suite 120, 19401 E. 40 Highway, Independence, MO 64055, (816) 795-8336. 